\title{
ALLOCATION OF STEADY-STATE AREAS OF TOTAL ELECTRICAL LOAD SCHEDULES OF 10/0.4 KV TRANSFORMER SUBSTATIONS LOCATED IN RESIDENTIAL AREAS
}

\author{
O. DOVGALYUK ${ }^{*}$, I. SHCHERBAK ${ }^{2}$, Y. KOVALOVA ${ }^{2}$, V. KOROBKA ${ }^{2}$ \\ ${ }^{1}$ National Technical University "Kharkiv Polytechnic Institute", Kharkiv, UKRAINE \\ ${ }^{2}$ O.M. Beketov National University of Urban Economy in Kharkiv, Kharkiv, UKRAINE \\ *e-mail:Dovgalyuk_O@khpi.edu.ua
}

\begin{abstract}
Improving the efficiency of regulating the parameters of distribution network modes is an actual task for the energy sector, requiring a detailed analysis of the nature of the total electrical load graphs of 10/0.4 kV transformer substations. The complexity of the problem in consideration is due to the fact that the load variation of transformer substations $10 / 0.4 \mathrm{kV}$ in residential areas occurs randomly, due to the significant number, wide range and probabilistic nature of the operating modes of connected consumers, and the lack of deterministic links between consumers of electricity. The investigated function of total load of transformer substations 10/0.4 kV on a daily interval is non-stationary, in this connection there was a necessity of allocation of stationarity areas for adjusting the process of regulation of parameters of electrical network modes. In order to solve this problem, total load graphs for 10/0.4 kV transformer substations located in a residential area were constructed based on experimental measurements of active and reactive loads. The use of these dependencies made it possible to analyse the distribution law for the active and reactive power of the total load of 10/0.4 kV transformer substations, which change in time is stochastic characterised. The use of probabilistic-statistical modelling was justified to reliably describe the load variation process of 10/0.4 $\mathrm{kV}$ transformer substations. The hypothesis of a normal law distribution of the functions under consideration was confirmed and parametric tests were performed. Fisher's F-criterion was used to confirm the hypothesis of variance constancy, and Student's t-criterion was used to confirm the hypothesis of mathematical expectation constancy. Using the fact of constancy of dispersions and expectations of investigated mode parameters, autocorrelation coefficients of investigated random functions were determined and autocorrelation function graphs were plotted. In order to approximate the functions under investigation, the autocorrelation function coefficients were determined using the least-squares method, and an analysis of the attenuation of the autocorrelation function was carried out. The calculations carried out have highlighted the areas of stationarity on the total load curves of the 10/0.4 kV transformer substations. These stationarity plots can be used for further modelling of load graphs and the formation of control actions to adjust the load of consumer regulators in order to equalise the overall electrical load graph, as well as for voltage regulation facilities, which will contribute to the required modes of operation of the electricity distribution networks.

Keywords: transformer substation; load graph; distribution law; parametric tests; mathematical expectation; dispersion; Pearson test; fisher's f-criterion; student's t-criterion; autocorrelation function

\section{ВИДІЛЕННЯ ДІЛЯНОК СТАЦІОНАРНОСТІ ГРАФІКІВ СУМАРНИХ ЕЛЕКТРИЧНИХ НАВАНТАЖЕНЬ ТРАНСФОРМАТОРНИХ ПІДСТАНЦЙ 10/0,4 КВ, РОЗТАШОВАНИХ В СЕЛЬБИЩНИХ ЗОНАХ}

\author{
О. М. ДОВГАЛЮК, І. Є. ЩЕРБАК ${ }^{2}$ Ю. В. КОВАЛЬОВА
}

\author{
${ }^{1}$ Національний технічний університет «Харківський політехнічний інститут», м. Харків, УКРАЇНА \\ ${ }^{2}$ Харківський національний університет міського господарства імені О.М. Бекетова, м. Харків, УКРАЇНА
}

\begin{abstract}
АНОТАЦІЯ Підвищення ефективності регулювання параметрів режимів розподільних електричних мереж є актуальним завданням для енергетики, що вимагае детального аналізу характеру графіків сумарних електричних навантажень трансформаторних підстаниій 10/0,4 кB. Складність даної проблеми обумовлена тим, щзо зміна навантаження трансформаторних підстаниій 10/0,4 кB сельбищних зон відбувається випадковим чином, щзо обумовлено значною кількістю, широкою номенклатурою $і$ імовірнісним характером режсимів роботи підключених споживачів, а також відсутністю детермінованих зв'язків між споживачами електричної енергії. Досліджувана функиія сумарного навантаження трансформаторних підстанцій 10/0,4 кВ на добовому інтервалі є нестаціонарною, в зв'язку з чим виникла необхідність виділення ділянок стаціонарності для коригування процесу регулювання параметрів режимів електричноі мережі. Для вирішення цього завдання були побудовані сумарні графіки навантаження для трансформаторних підстанцій 10/0,4 кB, розташованих в сельбищній зоні, на підставі експериментальних вимірювань величини активного і реактивного навантаження. Використання побудованих залежностей дозволило виконати аналіз закону розподілу для активної $i$ реактивної потужності сумарного навантаження трансформаторних підстанцій 10/0,4 кB, зміна яких у часі носить стохастичний характер. Для достовірного опису процесу зміни навантаження трансформаторних підстанцій 10/0,4 кB було обтрунтовано застосування ймовірнісно-статистичного методу моделювання. Була підтверджена гіпотеза про нормальний закон розподілу досліджуваних функиій $і$ виконані параметричні тести. Для підтвердження гіпотези про постійність дисперсій застосовувався F-критерій Фішера, а для підтвердження гіпотези про постійність математичного очікування - t-критерій Стьюдента. Використовуючи факт постійності дисперсій $i$ математичних очікувань досліджуваних параметрів режиму, були визначені коеріцієнти автокореляиії досліджуваних випадкових функцій $i$
\end{abstract}


побудовані графіки автокорелящуійних функцій. 3 метою апроксимаџії досліджуваних функцї були визначені коефіцієнти автокореляційних функиій, для чого використаний метод найменших квадратів, а також проведено аналіз на загасання автокореляційної функції. Проведені розрахунки дозволили виділити на сумарних графіках навантаження трансформаторних підстанцій 10/0,4 кB ділянки стаціонарності. Дані ділянки стаціонарності можуть використовуватися для подальшого моделювання графіків навантаження $і$ формування керуючих впливів для коректування навантаження споживачів-регуляторів з метою вирівнювання загального графіка електричного навантаження, а також для засобів регулювання напруги, щчо сприятиме забезпеченню необхідних режимів роботи розподільних електричних мереж.

Ключові слова: трансформаторна підстанція; графік навантаження; закон розподілу; параметричні тести; математичне очікування; дисперсія; критерій Пірсона; F-критерій Фішера; $t$-критерій Стьюдента; автокореляційна функиія

\section{Formulation of the problem}

The current trend in the energy sector is the active introduction of smart grid technologies, one component of which are systems for the automatic control of operating parameters in electrical networks. Over the last decades, there has been a significant increase in load density in residential areas as well as a strong change in consumer load patterns, leading to an increase in the unevenness of the total electrical load graphs of transformer substations (TS) in the urban electricity distribution networks. At the same time, the issues of ensuring the quality of electricity in accordance with current standards [1] become particularly relevant with the introduction of a liberalised electricity market in Ukraine. This leads to the need to improve the efficiency of the mode control process in electricity distribution networks.

An analysis of the characteristics of changes in the parameters of the modes of operation of modern electricity distribution networks must be carried out to solve this problem, and the regularities of this process must be determined in order to improve the efficiency of their regulation. It should be noted that the main mode parameters (current, voltage, power) are random variables that can acquire unknown values in advance. At the same time on the graphs of electrical loads of transformer substations 10/0.4 kV, from which consumers of residential areas receive power supply, it is possible to allocate characteristic zones of the maximum, minimum and average power consumption. The pattern of changes in the level of electricity consumption during the day is associated with the rhythms of life. Knowledge of the patterns of the main parameters change of the mode allows you to perform control actions to optimise the operation of electrical networks.

\section{Analysis of publications}

Analysis of the graphs of the electrical load of the $10 / 0.4 \mathrm{kV}$ substation indicates that parametric autoregression models are used to determine the loads at the design stage [2]. This model is used to describe stationary and non-stationary time series. The disadvantage of this model is the lack of connection with the actual state of the object, respectively, its use for TS $10 / 0.4 \mathrm{kV}$ residential areas is not justified.

Each $10 / 0.4 \mathrm{kV}$ TS of the residential area must have its own statistical models of electricity consumption, reflecting the individual characteristics of the operation modes of connected consumers. Ergorical random processes are allocate from stationary random processes, in which the probabilistic characteristics determined by the ensemble and one implementation coincide. This indicates that one sufficiently long implementation contains information about the static properties of the whole random process [3]. The obtained mathematical model allows to estimate and forecast with rather high degree of consumption accuracy of electric energy on $10 / 0,4 \mathrm{kV}$ TS, and also character of this consumption. This model includes both the accumulated information on the nature of electricity consumption and the results of calculations, reflected numerically [4]. In [5] a research was carried out and a function of the voltage expectation change is given. An analysis of the impact of the probabilistic nature of electricity network loads on the value of electricity quality indicators has been carried out in [6].

The application of a controlled load that is connected to the active electrical distribution network is considered by the authors in [7] to solve the problem of taking into account the structure of the electrical network when determining the substation capacity. In addition, a considerable part of research is devoted to the calculation and analysis of the load capacity of power transformers with regard to their design and electromechanical characteristics [8], as well as the analysis of reliability and power quality for transformer substations in electricity distribution networks $[9,10]$.

Also noteworthy are studies that focus on estimating the load of complex electrical networks based on transformer measurements and load forecasts [11,12], which take into account realistic conditions of stochastic load variation. In addition, the application of various methods for probabilistic load forecasting in electricity networks allows design and operational problems to be solved $[13,14]$.

Thus, no full-fledged modelling of electricity load graphs and their analysis for improved regulation of electricity network parameters has been carried out.

\section{The purpose of the article}

Determine the stages of allocation of stationary areas on the graphs of the electrical load of $10 / 0.4 \mathrm{kV}$ TS of residential areas. 


\section{Basic research materials}

Factors affecting the magnitude of the load are periodic and random. Periodic factors are due to natural cycles, technological features, mode of work and rest, lifestyle. During the year there is a decrease in load during the non-heating period and its increase in the winter months; during the week - decreasing the load on weekends; during the day - decreasing the load at night and increasing in the morning and evening hours. Random factors are caused by a number of stochastic factors, including load fluctuations associated with the simultaneous switching on and off of electrical receivers, the impact of changes in weather conditions, lighting, etc. [15].

Accordingly, there are problems of research and calculation of the parameters of the regime in the range of their change, the calculation of the values that characterize their scatter. The basis for this is statistical material and methods of probability theory.

The power consumed by the $10 / 0.4 \mathrm{kV}$ TS is a continuous random variable [16]. Given that the argument of the random function is the time $t$, the graphs of electrical loads is the implementation of a random process of power change. Average $P_{\mathrm{av}}$, root mean square (effective) $P_{e v}$ and maximum $P_{\max }$ power refers to the probabilistic characteristics the graphs of electrical loads.
The ratio between its ordinates at different times $t_{1}$, $t_{2}=t_{1}+\tau$ is probabilistic. Probabilistic methods take into account the random nature of the process of electricity consumption, changes in equipment (operating mode, winding temperature, etc.).

In the general case, the graphs of electrical loads are combinations of two components: a component that changes slowly due to the presence of morning and evening maxima, and a component that changes rapidly due to the presence of abrupt loads. Both of these components are usually statistically independent. Thus, such GEN are characterized by changes in their numerical characteristics during the day and are non-stationary processes.

In a nonstationary random process in characteristic periods of time it is possible to determine areas of stationarity. It should be noted that the nature of the process depends on the accepted value $\Delta t$. The stochastic process can be stationary, quasi-stationary or piecewisestationary.

The process of electricity consumption of major consumers $10 / 0.4 \mathrm{kV} \mathrm{TS}$, that is, their the graphs of electrical loads, can be represented by a set of timeordered random variables $P\left(\tau_{1}\right), P\left(\tau_{2}\right), \ldots, P\left(\tau_{n}\right)$, where $\tau_{i}<\tau_{i+1}$. A research of the random process $P^{*}\left(t_{\mathrm{i}}\right)$ of changing the load of $10 / 0.4 \mathrm{kV}$ TS was carried out, which is shown in Fig. 1.

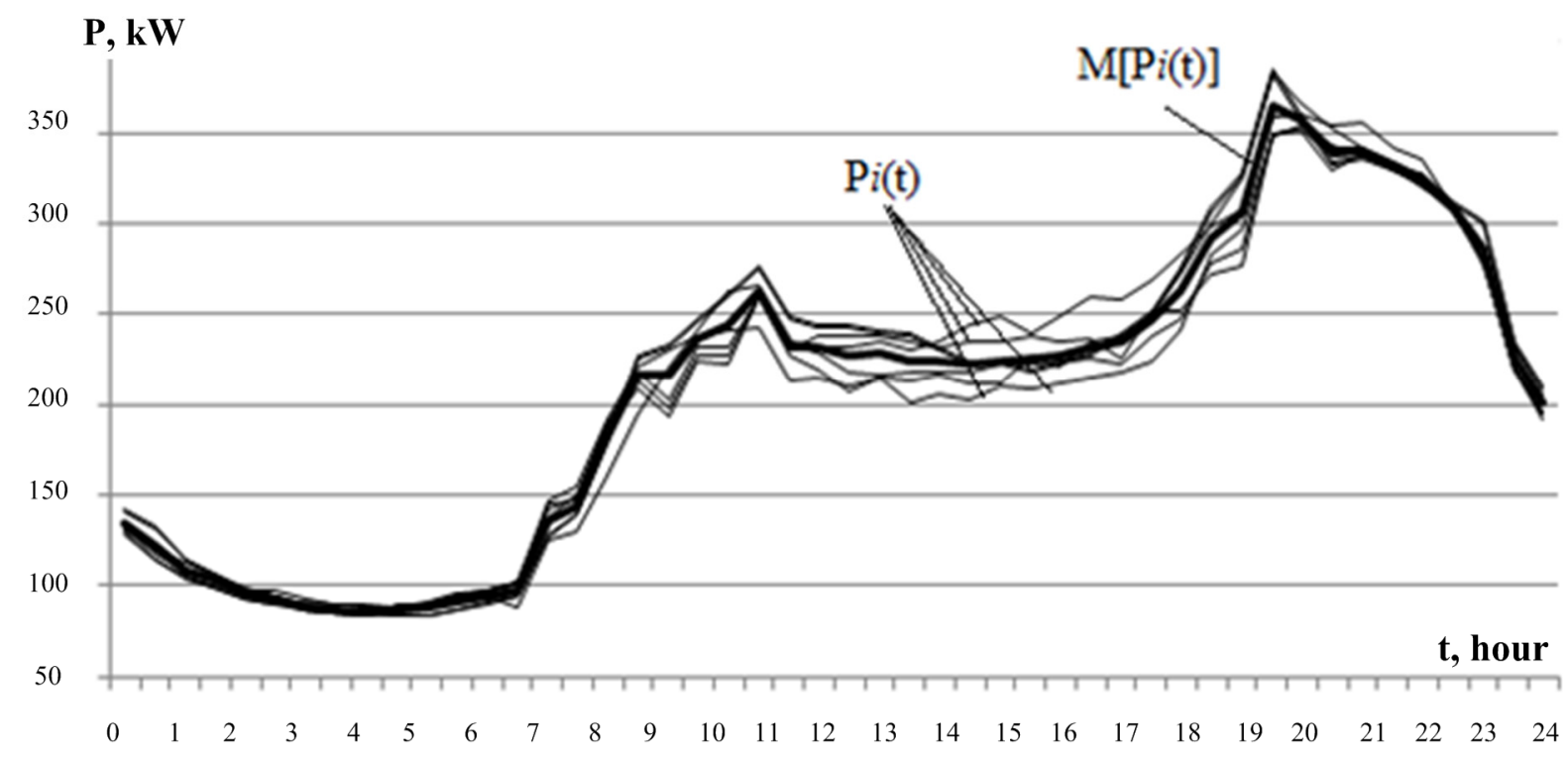

Fig. 1 - Realization of random load function of 10/0.4 kV TS and its mathematical expectation

Combined probabilistic-deterministic models provide the best forecasting accuracy and adaptability to the power consumption process [17]. The actual load $P\left(\tau_{\mathrm{i}}\right)$ is represented as a set of standardized graph (base component, deterministic trend) and the residual component. The additive model has been most widely used in the power industry [18]:

$$
P\left(\tau_{i}\right)=q\left(\tau_{i}\right)+\varepsilon\left(\tau_{i}\right), i=1,2, \ldots, n,
$$

where $q\left(\tau_{i}\right)$ - non-random (deterministic) component, which may include one or more of the following components: trending $t\left(\tau_{i}\right)$, seasonal $s\left(\tau_{i}\right) \mathrm{s}$ and periodic $p\left(\tau_{i}\right) ; \varepsilon\left(\tau_{i}\right)$ - random component, an integral part of the time series that remains after the selection of systematic 
components. It reflects the influence of numerous random factors and is a random, irregular component.

The stationary random process can be analyzed starting from any point in time, because it is in a state of probable equilibrium, ie the numerical characteristics of random variables $P\left(\tau_{\mathrm{i}}\right)$ do not depend on time $\tau_{\mathrm{i}}$.

We assume that the moments of measurement $\tau_{\mathrm{i}}$ are equidistant from each other by the value of $\Delta_{\tau}$, ie for any $i$, takes place

$$
\tau_{i+1}=\tau_{i}+\Delta_{\tau}
$$

From model (1) it follows that at each moment $\tau_{\mathrm{i}}$ the value of $P\left(\tau_{\mathrm{i}}\right)$ is random, subject to some distribution that depends on the distribution of the random component $\varepsilon\left(\tau_{i}\right)$.

The presence of a large number of electrical receivers in combination with the difference in the modes of their operation make it necessary to assess the stationarity of the load function.

The first step in identifying areas of stationarity is to test the hypothesis of the distribution law. The estimation of the load distribution law was performed by analyzing a sample consisting of $n$ independent observations on a random variable $P(t)$. Next, the selection of the consistency criterion was performed (Pearson's consistency criterion was selected). Comparison of calculated and tabular values of $\chi^{2}$ and acceptance of the hypothesis of a normal distribution law with the level of significance $\alpha$. The time series is stationary in the narrow sense if for each moment of time the random variables $P\left(\tau_{\mathrm{i}}\right)$ have the same distribution laws. [19]:

Conditions of stationarity of a random process

1) consistency of mathematical expectation of the process:

$$
m_{x}(t)=m_{x}=\text { const; }
$$

2) constancy of process dispersion:

$$
D_{x}(t)=D_{x}=\text { const; }
$$

3) dependence of the correlation function on one argument, which is the difference between the arguments:

$$
K_{x}(t, t+\tau)=K_{x}(\tau) .
$$

The second step for the selection of stationary areas is to conduct parametric tests. The mathematical expectation and variance for model (1) at time $\tau_{\mathrm{i}}$ are determined by expressions:

$$
\begin{gathered}
M\left(P\left(\tau_{i}\right)\right)=q\left(\tau_{i}\right) \\
D\left(P\left(\tau_{i}\right)\right)=D\left(\varepsilon\left(\tau_{i}\right)\right)+0.179 \mathrm{P}_{g *} .
\end{gathered}
$$

Using Fisher's F-test, we test the hypothesis of constancy of variances. If this hypothesis is accepted, then the hypothesis of constancy of mathematical expectation is tested (Student's t-test). If the hypothesis of constancy of mathematical expectation is accepted, then the hypothesis of stationarity (in a broad sense) of the time series is accepted.

The time series is divided into two levels according to the number of values of the part, each of which is considered as some independent sample population with a normal distribution. If the time series tends to trend, then the averages calculated for each population should differ significantly. If the difference is insignificant, random, then the time series has no tendency. Thus, the test for the presence of a non-random component in the time series under study is to test the hypothesis of equality of the average of two normally distributed populations. Let the first part of $P^{(I)}$ contain $n_{I}$ observations

$P\left(\tau_{i}\right), i=1,2, \ldots, n_{I}$, and the other part $-P^{(I I)}$ contains $n_{I I}$ observations $P\left(\tau_{i}\right), i=n_{I}+1, \ldots, n_{I}+n_{I I}$.

For each part of the time series, calculate the sample mean $\bar{p}_{I}, \bar{p}_{I I}$ :

$$
\bar{p}_{i}=\frac{1}{n} \cdot \sum_{i=1}^{n} x_{i}=M\left[P_{i}(t)\right]
$$

where $i=I$, $I I$ (the first and second parts of the time series, accordingly).

Selective variances $D_{I}, D_{I I}$ :

$$
\begin{gathered}
D_{I}^{2}=\frac{1}{n_{I}-1} \cdot \sum_{i=1}^{n_{I}}\left(p_{i}-\bar{p}_{I}\right)^{2} \\
D_{I I}^{2}=\frac{1}{n_{I I}-1} \cdot \sum_{i=n_{I}+1}^{n_{I I}}\left(p_{i}-\bar{p}_{I I}\right)^{2} .
\end{gathered}
$$

In order to confirm that the variances of both parts of the series are the same, we use Fisher's F-test:

$$
F_{S}=\frac{\max \left(D_{I}^{2}, D_{I I}^{2}\right)}{\min \left(D_{I}^{2}, D_{I I}^{2}\right)},
$$

where $D_{I}^{2}, D_{I I}^{2}$ - variance estimates calculated by the first $n_{I}$ and second $n_{I I}$ parts of the time series. If the inequality does not hold:

$$
F_{\frac{\alpha}{2} ; n_{I}-1 ; n_{I I}-1} \leq F_{S} \leq F_{1-\frac{\alpha}{2} ; n_{I}-1 ; n_{I I}-1}
$$

then the hypothesis of constancy of variances is rejected with the level of significance $\alpha$ and it is necessary to accept the hypothesis of the non-random component presence of the time series, due to the fact that this component may affect other characteristics of the time series: variances, autocorrelation coefficients, etc.

If $s_{I}^{2}>s_{I I}^{2}$, then the hypothesis is accepted as an alternative hypothesis:

$$
H_{1}: \sigma_{I}^{2}>\sigma_{I I}^{2}
$$

in this case, the critical area is the interval $\left(F_{\text {кр }}, \infty\right)$, where the point $F_{\text {кр }}$ is determined by the condition: 


$$
P\left(F_{s}>F_{\text {кр }}\right)=\alpha,
$$

where $\quad \alpha$-the probability of the first kind error.

If the value of $F_{s}$ does not fall into the critical area, then the null hypothesis is accepted:

$$
H_{0}: \sigma_{I}^{2}=\sigma_{I I}^{2}
$$

If the hypothesis about the constancy of variances is accepted with the significance level $\alpha$ then the hypothesis about the constancy of the mean value of the time series is tested.

Lets formulate two statistical hypotheses:

$$
\begin{aligned}
& H_{0}: M\left(P\left(\tau_{i}\right)\right)=\text { const }, \\
& H_{1}: M\left(P\left(\tau_{i}\right)\right) \neq \text { const. }
\end{aligned}
$$

Calculate the value of Student's t-test:

$$
\begin{aligned}
K_{S}= & \frac{\bar{p}_{I}-\bar{p}_{I I}}{\sqrt{\left(n_{I}-1\right) s_{I}^{2}+\left(n_{I I}-1\right) s_{I I}^{2}}} \times \\
& \times \sqrt{\frac{n_{I} \cdot n_{I I}\left(n_{I}+n_{I I}-2\right)}{n_{I}+n_{I I}}} .
\end{aligned}
$$

If the inequality holds:

$$
K_{S}<t\left(1-\alpha, n_{I}+n_{I I}-2\right),
$$

then the hypothesis of the constancy of the mathematical expectation is accepted with the level of significance $\alpha$.

If the actual values of the Student's coefficients do not exceed the critical values in the selected areas of stationarity, this indicates the heteroskedasticity of the distribution residuals of the random variable. Thus, the hypothesis of the constancy of the mathematical expectation is accepted.

Acceptance of hypotheses about equality of variances and equality of mathematical expectations allows to accept a hypothesis about absence of a trend component in the given time series and to go to the third stage.

The next stage of the analysis of the stationarity of the load function at the selected intervals is the analysis of the autocorrelation function. The degree of statistical relationship between sequences $P\left(\tau_{1}\right), P\left(\tau_{2}\right), \ldots, P\left(\tau_{n}\right)$ and $P\left(\tau_{1+l}\right), P\left(\tau_{2+l}\right), \ldots, P\left(\tau_{n+l}\right)$, shifted relative to each other with a lag $l$, can be determined using the autocorrelation coefficient:

$$
\rho(l)=\frac{M\left[\left(P\left(\tau_{i}\right)-q\right)\left(P\left(\tau_{i+1}\right)-q\right)\right]}{\sigma^{2}} .
$$
the lag $l$ :

For a stationary time series $\rho(l)$ depends only on

$$
\rho(-l)=\rho(l) \text {. }
$$

The estimate for $\rho(l)$ is the sample autocorrelation coefficient determined by the formula:

$$
\begin{gathered}
\rho(l)=\left[(n-l) \sum_{i=1}^{n-l} p_{i} p_{i+l}-\right. \\
\left.-\left(\sum_{i=1}^{n-l} p_{i}\right) \cdot\left(\sum_{i=1}^{n-l} p_{i+l}\right)\right] / \\
{\left[\sqrt{(n-l) \sum_{i=1}^{n-l} p_{i}^{2}-\left(\sum_{i=1}^{n-l} p_{i}\right)^{2} \times}\right.} \\
\left.\times \sqrt{(n-l) \sum_{i=1}^{n-l} p_{i+l}^{2}-\left(\sum_{i=1}^{n-l} p_{i+1}\right)^{2}}\right] .
\end{gathered}
$$

As $l$ increases, the number of observation pairs $p_{i}, p_{i+1}$ decreases, so it is recommended $l \leq n / 4$. For a stationary time series with increasing lag $l$, the relationship of the terms $P\left(\tau_{i}\right), P\left(\tau_{i+l}\right)$ weakens and the absolute values of the autocorrelation coefficient $\rho(l)$ must decrease. At the same time, for the sample autocorrelation coefficient $r(l)$ the property of monotonic decline with increasing $l$ may be violated.

The autocorrelation coefficient characterizes the density of the linear relationship between random variables $P\left(\tau_{i}\right), P\left(\tau_{i+l}\right)$. Therefore, the value of the autocorrelation coefficient can be concluded about the presence of a linear (or close to linear) trend of the time series.

By the sign of the autocorrelation coefficient it is impossible to do a conclusion about the increasing or decreasing trend of time series values.

Sequence of autocorrelation coefficients $\rho(0), \rho(1), \rho(2)$ is an autocorrelation function of the time series. Analysis of the autocorrelation function allows to identify the structure of the time series, ie the presence of components in it $t\left(\tau_{i}\right), s\left(\tau_{i}\right), p\left(\tau_{i}\right)$.

If the largest was the autocorrelation coefficient $\rho(1)$, then the series under study contains only the trend component. If the largest was the autocorrelation coefficient $\rho(l)$, then the series contains oscillations with a frequency of time moments $l$, ie the period of oscillation is equal to $l \cdot \Delta_{r}$. If neither of the coefficients $\rho(l)$ is significant, then one can make one of two assumptions about the structure of the series:

1) the time series does not contain trend and cyclic fluctuations, ie is white noise with $\rho(l)$;

2 ) the time series contains a strong nonlinear trend, for the detection of which it is necessary to conduct additional analysis.

Therefore, the autocorrelation coefficient and the autocorrelation function should be used to identify in the time series of trend and periodic seasonal components.

The hypothesis about the ergodicity of the process is accepted and according to the results of the values of the autocorrelation coefficients the reference model of the 
correlation function is chosen - exponentially cosine, which is described by the analytical dependence [20]:

$$
R(\tau)=D \cdot e^{-\alpha \tau} \cdot \cos (\beta \tau),
$$

where $\quad \mathrm{D}-$ variance of a random function; $\alpha$ i $\beta-$ coefficients determined by the method of least squares [21].

For the practical construction of the autocorrelation function on stationarity intervals, it is advisable to use software packages for statistical data analysis (STATISTICA, STATGRAPHICS PLUS and others). An example of using the package to construct a STATISTICA autocorrelation function is shown in Fig. 2.

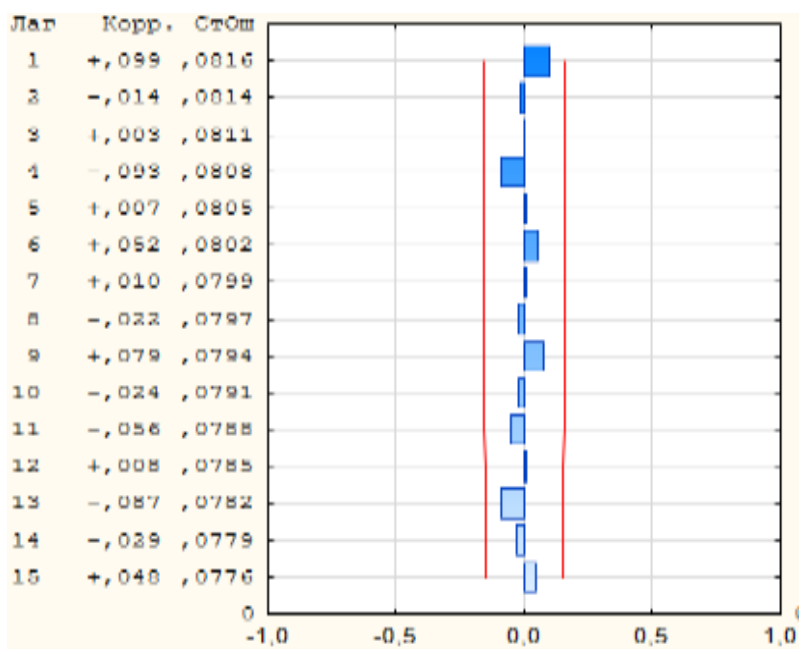

Fig. 2-Autocorrelation function at the daily interval (STATISTICA)

The approximated function for the sequence of daily intervals is presented in Fig. 3.

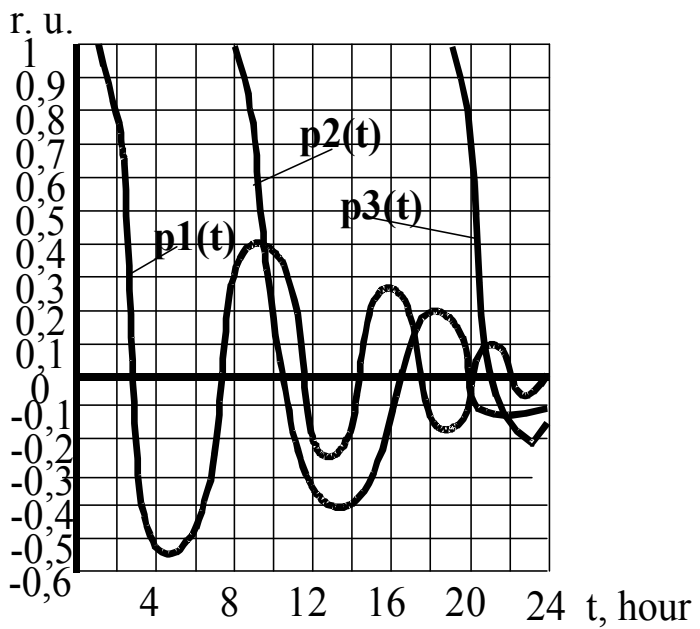

Fig. 3-An approximated function at the daily interval sequence

Analysis of the values of $\rho(l)$ and the correlogram allows us to conclude that the time series are stationary at all intervals, both for maximum and minimum load modes.

The calculated value of the load is found by the formula [22]:

$$
P_{i}(t)=M\left[P_{i}(t)\right]+\beta \sigma\left[P_{i}(t)\right],
$$

where $\quad M\left[P_{i}(t)\right]-$ mathematical expectation of load at a time $t ; \sigma\left[P_{i}(t)\right]$ - standard deviation of the load at the time $t ; \beta$ - the coefficient of a random value scatter of the load, taking into account the intensity of the random values scatter of the load near the accepted calculated value [22]. applied:

In probability theory, the rule of three sigmas is

$$
P_{\text {max }}=P_{\mathrm{cp}} \pm 3 \sigma \text {, }
$$

which under the normal distribution law corresponds to the ultimate probability 0.9973 . The probability of exceeding the load on $\pm 0.5 \%$ corresponds $\beta=2.5 ; \beta=2$ corresponds to the probability 0.975 . For $\beta=1.65$ is provided $\pm 5 \%$ of error probability. For the accuracy of the calculation $\pm 10 \%$, which corresponds to the error of engineering calculations, the value of the coefficient $\beta=1.0$.

Simulated graphs of electrical load allow to take into account the real process of load behavior, which is an important task for the implementation of high-quality modeling of consumers-regulators [23].

\section{Conclusions}

The change in the load of $10 / 0.4 \mathrm{kV}$ TS is stochastic in nature, which is non-stationary at the daily interval. For certain stages of allocation of stationary areas it is necessary to determine the distribution law for the allocated time interval, to check the normal distribution law by Pearson's criterion. In the case of a normal distribution law, the next step is to check the stationarity of the time series by parametric tests, namely the criteria for checking the constancy of variance (Fisher's F-test) and mathematical expectation (Student's t-test) and the correlation function. In the case of ergodicity of the process in the allotted time, the process is considered stationary. The final stage is to determine the value of the numerical characteristics of the studied processes in the stationary areas and the construction of a probabilistic mathematical model of the load.

\section{Список літератури}

1. Voltage characteristics of general purpose electricity supply systems (EN 50160:2010, IDT), Ministry of Economic Development and Trade of Ukraine, DSTU EN 50160:2014, 2014.

2. Справочник по энергоснабжению $u$ электрооборудованию промышленных предприятий $u$ общественных зданий / Под общей ред. профессоров МЭИ(ТУ) С.И. Гамазина, Б.И. Кудрина, С.А. Цырука. М.: Издательский дом МЭИ, 2010. 
3. Myers W., Ye M. Probability and Statistics for Engineers and Scientists. 2012. P. 813. URL: http://www.elcomhu.com/Mshtrk/Statstics/9th\%20txt\%20book.pdf

4. Herman R., Gaunt C. T. A Practical Probabilistic Design Procedure for LV Residential Distribution Systems. IEEE Transactions on Power Delivery. Oct. 2008. Vol. 23. Is. 4.

5. Говоров П. П. Керування режимами розподільних електричних мереж міст на основі гнучких систем: дис. ... д-ра техн. наук: 05.14.02 / Нац. ун-т «Львівська політехніка». Львів, 2001. 457 с.

6. Довгалюк О. Н. Учет влияния вероятностного характера нагрузок электрических сетей на величину показателей качества электроэнергии. Вестник Начионального технического университета “ХПИ”. 2003. № 11. С. 4152.

7. Liu W., Liu Y., Niu S., Liu Z. Assessment Method for Substation Capacity Credit of Generalized Power Source Considering Grid Structure. Sustainability. 2017. № 9. P. 928. doi: 10.3390/su9060928.

8. Micu D. D., Rusina A. G., Naumov O. V., Gorlov A. N. Calculation of loading ability of power transformers taking into account electromechanical characteristics. International Scientific and Technical Conference Smart Energy Systems 2019 (SES-2019). 2019. Vol. 124. P. 02006. doi: $10.1051 / \mathrm{e} 3$ sconf/201912402006.

9. Adesina L. M., Abdulkareem A., Ogunbiyi O., Ibrahim O. On-load measurement method for the reliability of distribution transformers. MethodsX. 2020. Vol. 7. P. 101089. doi: 10.1016/j.mex.2020.101089.

10. Syahputra R., Arrozak L. F. Power Transformer Loading Analysis in order to improve the Reliability of a Substation. Journal of Electrical Technology UMY (JET-UMY). 2017. Vol. 1. No. 4. P. 165-175.

11. Rong H., Leon F. Load Estimation of Complex Power Networks from Transformer Measurements and Forecasted Loads. Complexit. 2020. Vol. 2020. P. 2941809. doi: $10.1155 / 2020 / 2941809$.

12. Zhao J., Zhang G., Das K. et al. Power system real-time monitoring by using PMU-based robust state estimation method. IEEE Transactions on Smart Grid. 2016. Vol. 7. No. 1. P. 300-309.

13. Liu B., Nowotarski J., Hong T., Weron R. Probabilistic load forecasting via quantile regression averaging on sister forecasts. IEEE Transactions on Smart Grid. 2017. Vol. 8. No. 2. P. 730-737.

14. Kong W., Dong Z. Y., Hill D. J., Luo F., Xu Y. Short-term residential load forecasting based on resident behaviour learning. IEEE Transactions on Power Systems. 2018. Vol. 33. No. 1. P. 1087-1088.

15. Ziegler F., Seim S., Verwiebe P., Müller-Kirchenbauer J. A Probabilistic Modelling Approach for Residential Load Profiles. Energie und Ressourcen. P. 1-28. doi: 10.5281/zenodo.3689339.

16. Федоров А. А. Основы электроснабжения промышленных предприятий. Москва: Энергия, 1972. $312 \mathrm{c}$.

17. Sarantakos I., Greenwood D. M., Zografou-Barredo N-M., Vahidinasab V., Taylor P.C. A probabilistic method to quantify the capacity value of load transfer. International Journal of Electrical Power \& Energy Systems. 2020. Vol. 123. P. 1-12.

18. Крамер Г. Математические методы статистики. Москва: Мир, 1975. 648 с.

19. Коломієць С. В. Теорія випадкових процесів. Суми: ДВНЗ «УАБС НБУ», 2011. 80 с.
20. Білак Н.В., Скляр О.О. Апроксимативно-спектральний аналіз випадкового процесу. Проблеми інформатизаиії та управління. 2015. № 2. С. 26-31.

21. Веприк Ю. Н. Комплексное моделирование электрических систем в стационарных режимах. Вестник Харьковского государственного политехнического университета. 2000. № 112. С. 22-27.

22. Жежеленко И. В., Саенко Ю. Л., Степанов В. П. Методы вероятностного моделирования в расчетах характеристик электрических нагрузок потребителей. Москва: Энергоатомиздат, 1990. 128 с.

23. Shcherbak I. Mathematical model of consumer regulators management for alignment of electric load graphs of transformer substation 10/0.4 kV. Світлотехніка та електроенергетика. 2019. № 3. С. 125-129.

\section{References (transliterated)}

1. Voltage characteristics of general purpose electricity supply systems (EN 50160:2010, IDT), Ministry of Economic Development and Trade of Ukraine, DSTU EN 50160:2014, 2014.

2. Handbook of power supply and electrical equipment of industrial enterprises and public buildings. Under the general editorship. professors MEI (TU) S.I. Gamazina, B.I. Kudrina, S.A. Tsyruka. M.: MEI Publishing House, 2010.

3. Myers W., Ye M. Probability and Statistics for Engineers and Scientists. 2012. P. 813. Available at: http://www.elcomhu.com/Mshtrk/Statstics/9th\%20txt\%20book.pdf

4. Herman R., Gaunt C. T. A Practical Probabilistic Design Procedure for LV Residential Distribution Systems. IEEE Transactions on Power Deliver, Oct. 2008, Vol. 23, Is. 4.

5. Govorov P. P. Control of modes of distributive electric networks of cities on the basis of flexible systems: dis. ... Dr. Tech. Science: 05.14.02 / Nat. Lviv Polytechnic University. Lviv, 2001, $457 \mathrm{p}$.

6. Dovgalyuk O. N. Accounting for the influence of the probabilistic nature of the loads of electrical networks on the value of indicators of the quality of electricity. Bulletin of the National Technical University "KhPI", 2003, No. 11, pp. 41-52.

7. Liu W., Liu Y., Niu S., Liu Z. Assessment Method for Substation Capacity Credit of Generalized Power Source Considering Grid Structure. Sustainability, 2017, 9, p. 928, doi: 10.3390/su9060928.

8. Micu D. D., Rusina A. G., Naumov O. V., Gorlov A. N. Calculation of loading ability of power transformers taking into account electromechanical characteristics. International Scientific and Technical Conference Smart Energy Systems 2019 (SES-2019), 2019, Vol. 124, p. 02006, doi: 10.1051/e3sconf/201912402006.

9. Adesina L. M., Abdulkareem A., Ogunbiyi O., Ibrahim O. On-load measurement method for the reliability of distribution transformers. MethodsX, 2020, Vol. 7, p. 101089, doi: 10.1016/j.mex.2020.101089.

10. Syahputra R., Arrozak L. F. Power Transformer Loading Analysis in order to improve the Reliability of a Substation. Journal of Electrical Technology UMY (JET-UMY), 2017, Vol. 1, No. 4, pp. 165-175.

11. Rong H., Leon F. Load Estimation of Complex Power Networks from Transformer Measurements and Forecasted Loads. Complexit, 2020, Vol. 2020, p. 2941809, doi: $10.1155 / 2020 / 2941809$. 
12. Zhao J., Zhang G., Das K. et al. Power system real-time monitoring by using PMU-based robust state estimation method. IEEE Transactions on Smart Grid, 2016, Vol. 7, No. 1 , pp. 300-309.

13. Liu B., Nowotarski J., Hong T., Weron R. Probabilistic load forecasting via quantile regression averaging on sister forecasts. IEEE Transactions on Smart Grid, 2017, Vol. 8, No. 2, pp. 730-737.

14. Kong W., Dong Z. Y., Hill D. J., Luo F., Xu Y. Short-term residential load forecasting based on resident behaviour learning. IEEE Transactions on Power Systems, 2018, Vol. 33, No. 1, pp. 1087-1088.

15. Ziegler F., Seim S., Verwiebe P., Müller-Kirchenbauer J. A Probabilistic Modelling Approach for Residential Load Profiles. Energie und Ressourcen, pp. 1-28, doi: 10.5281/zenodo.3689339.

16. Fedorov A.A. Fundamentals of power supply of industrial enterprises. Moscow. Energy, 1972. 312 p.

17. Sarantakos I., Greenwood D. M., Zografou-Barredo N-M., Vahidinasab V., Taylor P.C. A probabilistic method to quantify the capacity value of load transfer. International
Journal of Electrical Power \& Energy Systems, 2020, Vol. 123, pp. 1-12.

18. Kramer G. Mathematical methods of statistics. Moscow. Mir, 1975. 648 p.

19. Kolomiets S. V. Theory of random processes. Sumy: DVNZ «UABS NBU», 2011. 80 p.

20. Bilak N.V., Sklyar O.O. Approximate spectral analysis of random process. Problems of informatization and management, 2015, 2, pp. 26-31.

21. Veprik Yu. N. Complex modeling of electrical systems in stationary modes. Bulletin of Kharkiv State Polytechnic University. Kharkiv: KhGPU, 2000, 112, pp. 22-27.

22. Zhezhelenko I. V., Saenko Yu. L., Stepanov V. P. Methods of probabilistic modeling in calculations of characteristics of electric loads of consumers. Moscow. Energoatomizdat, 1990. $128 \mathrm{p}$.

23. Shcherbak I. Mathematical model of consumer regulators management for alignment of electric load graphs of transformer substation $10 / 0.4 \mathrm{kV}$. Lighting engineering and electric power, 2019, 3, c. 125-129.

\section{Відомості про авторів (About authors)}

Dovgalyuk Oksana - Candidate of Technical Sciences, Assoc. prof., National Technical University "Kharkiv Polytechnic Institute", Professor of Department of Electric power transmission, Kharkiv, Ukraine; ORCID: https://orcid.org/0000-0003-1994619X; e-mail: Dovgalyuk_O@khpi.edu.ua.

Довгалюк Оксана Миколаӥвна - кандидат технічних наук, доцент, Національний технічний університет «Харківський політехнічний інститут», професор кафедри передачі електричної енергії; Харків, Україна; ORCID: https://orcid.org/00000003-1994-619X; e-mail: Dovgalyuk_O@khpi.edu.ua.

Shcherbak Iryna - Candidate of Technical Sciences, O.M. Beketov National University of Urban Economy in Kharkiv, assistant of Department of power supply systems and electricity consumption of cities, Kharkiv, Ukraine; ORCID: http://orcid.org/0000-0003-1211-4665; e-mail: ie.shcherbak@gmail.com.

Щербак Ірина Свгенівна - кандидат технічних наук, Харківський національний університет міського господарства імені O.M. Бекетова, асистент кафедри систем електропостачання та електроспоживання міст, Харків, Україна; ORCID: http://orcid.org/0000-0003-1211-4665; e-mail: ie.shcherbak@gmail.com.

Yuliia Kovalova - Candidate of Technical Sciences, O.M. Beketov National University of Urban Economy in Kharkiv, Assoc. prof. of Department of power supply systems and electricity consumption of cities, Kharkiv, Ukraine; ORCID: https://orcid.org/0000-0002-2931-9176; e-mail: kovalova.jv@gmail.com.

Ковальова Юлія Вікторівна - кандидат технічних наук, доцент, Харківський національний університет міського господарства імені О.М. Бекетова, доцент кафедри систем електропостачання та електроспоживання міст, Харків, Україна; ORCID: https://orcid.org/0000-0002-2931-9176, e-mail: kovalova.jv@gmail.com.

Korobka Volodymyr - O.M. Beketov National University of Urban Economy in Kharkiv, Senior Lecturer of Department of power supply systems and electricity consumption of cities, Kharkiv, Ukraine; ORCID: https://orcid.org/0000-0002-1398-8084; email: korobkat62@ukr.net.

Коробка Володимир Олександрович - Харківський національний університет міського господарства імені О.М. Бекетова, старший викладач кафедри систем електропостачання та електроспоживання міст, Харків, Україна; ORCID: https://orcid.org/0000-0002-1398-8084; e-mail: korobkat62@ukr.net.

Please cite this article as:

Dovgalyuk O., Shcherbak I., Kovalova Y., Korobka V. Allocation of steady-state areas of total electrical load schedules of 10/0.4 kv transformer substations located in residential areas. Bulletin of the National Technical University "KhPI". Series: New solutions in modern technology. - Kharkiv: NTU "KhPI", 2021, no. 3 (9), pp. 11-19, doi:10.20998/2413-4295.2021.03.02.

Будь ласка, посилайтесь на ию статтю наступним чином:

Довгалюк О. М., Щербак І. Є., Ковальова Ю. В., Коробка В. О. Виділення ділянок стаціонарності графіків сумарних електричних навантажень трансформаторних підстанцій $10 / 0,4$ кB, розташованих в сельбищних зонах. Bicник Начіонального технічного університету «ХПІ». Серія: Нові рішення в сучасних технологіях. - Харків: НТУ «ХПІ». 2021. № 3 (9). C. 11-19. doi:10.20998/2413-4295.2021.03.02. 
Пожалуйста, ссылайтесь на эту статью следующим образом:

Довгалюк О. Н., Щербак И. Е., Ковалева Ю. В., Коробка В. А. Выделения участков стационарности графиков суммарных электрических НАГРУЗОК трансформаторных подстанций 10/0,4 кВ, расположенных в селитебных зонах. Вестник Начионального технического университета « ХПИ». Серия: Новые решения в современных технологиях. Харьков: НТУ «ХПИ». 2021. № 3 (9). С. 11-19. doi:10.20998/2413-4295.2021.03.02.

АННОТАЦИЯ Повышение эффективности регулирования параметров режимов распределительных электрических сетей является актуальной задачей для энергетики, требующей детального анализа характера графиков сумларных электрических нагрузок трансформаторных подстанций 10/0,4 кВ. Сложность рассматриваемой проблемы обусловлена тем, что изменение нагрузки трансформаторных подстаниий 10/0,4 кB селитебных зон происходит случайным образом, что обусловлено значительным количеством, широкой номенклатурой и вероятностным характером режимов работы подключенных потребителей, а также отсутствием детерминированных связей между потребителями электрической энергии. Исследуемая функиия суммарной нагрузки трансформаторных подстанций 10/0,4 кВ на суточном интервале является нестационарной, в связи с чем возникла необходимость выделения участков стационарности для корректировки прочесса регулирования параметров режимов электрической сети. Для решения этой задачи были построены суммарные графики нагрузки для трансформаторных подстанций 10/0,4 кB, расположенных в селитебной зоне, на основании экспериментальных измерений величины активной и реактивной нагрузки. Использование построенных зависимостей позволило выполнить анализ закона распределения для активной и реактивной мощности суммарной нагрузки трансформаторных подстанций 10/0,4 кВ, изменение которых во времени носит стохастический характер. Для достоверного описания проиесса изменения нагрузки трансформаторных подстанций 10/0,4 кВ было обосновано применение вероятностно-статистического метода моделирования. Была подтверждена гипотеза о нормальном законе распределения исследуемых функиий и выполнены параметрические тесты. Для подтверждения гипотезы о постоянстве дисперсий применялся F-критерий Фишера, а для подтверждения гипотезы о постоянстве математического ожсдания t-критерий Стьюдента. Используя факт постоянства дисперсий и математических ожиданий исследуемых параметров режима, были определены коэффиииенты автокорреляции исследуемых случайных функиий и построены графики автокорреляционных функций. С целью аппроксимации исследуемых функции были определены коэффициенты автокорреляционных функиий, для чего использован метод наименьших квадратов, а также проведен анализ на затухание автокоррелячионной функции. Проведенные расчеты позволили выделить на суммарных графиках нагрузки трансформаторных подстанций 10/0,4 кB участки стационарности. Данные участки стационарности могут использоваться для дальнейшего моделирования графиков нагрузки и формирования управляюших воздействий для корректировки нагрузки потребителей-регуляторов с иелью выравнивания общего графика электрической нагрузки, а также для средств регулирования напряжения, что будет способствовать обеспечению требуемых режимов работь распределительных электрических сетей.

Ключевые слова: трансформаторная подстанция; график нагрузки; закон распределения; параметрические тесты; математическое ожидание; дисперсия; критерий Пирсона; F-критерий Фишера; $t$-критерий Cтьюдента; автокорреляционная функцияя. 